\title{
Diagenesis of Late Miocene micritic lacustrine carbonates, Madrid Basin, Spain
}

\author{
V.P. Wright ${ }^{\text {a.c., }}$, A.M. Alonso Zarza ${ }^{\text {b }}$, M.E. Sanz ${ }^{\text {b }}$, J.P. Calvo ${ }^{\text {b }}$ \\ "Postgraduate Research Institute for Sedimentology, The University of Reading, P.O. Box 227, Whiteknights, Reading RG6 6AB, UK \\ ${ }^{h}$ Departamento de Petrología y Geoquímica, Facultad de Ciencias Geológicas, Universidad Complutense, 28040 Madrid, Spain \\ 'Department of Earth Sciences, University of Wales Cardiff. Cardiff. CFI $3 Y$ Y, UK
}

\begin{abstract}
Mud-grade lacustrine limestones of Miocene age from the Madrid Basin, Spain, reveal varied and complex diagenetic histories. Microporous micrites occur as well as micrites with anhedral mosaics. The micrites have recrystallized from a metastable precursor, in part under sub-oxic meteoric diagenetic conditions probably before extensive karstification in the Pliocene. The absence of aragonite relics, their mainly micritic microfabric, low $\mathrm{Sr}$ content and covariant trend of $\mathrm{Sr}$ and $\mathrm{Mg}$ suggest that the micrites formed from mainly high-magnesian calcite muds. Lacustrine micrites can be compared to marine forms and criteria used to assess the composition of the marine precursor muds can be applied to lacustrine limestones to complement other techniques to identify original lake water compositions.
\end{abstract}

Keywords: diagenesis; lacustrine; micrite; microporosity; Miocene

\section{Introduction}

Despite some thirty years of intensive study of carbonate diagenesis, some aspects remain still relatively poorly understood. Carbonate mudrocks, although volumetrically dominant in many marine and non-marine carbonate successions, have received little attention compared to dolomites, or to cements in grain-rich carbonates. Non-marine carbonates in general have received even less attention yet

\footnotetext{
* Corresponding author. Present address: Department of Earth Sciences, Cardiff University, Cardiff, CF2 3YE, UK and BG Exploration \& Production, 100 Thames Valley Park Drive, Reading RG6 IPT, UK. Tel.: +44 (1222) 874943; Fax: +44 (1222) 874326 .
}

they present particular challenges because chemical changes in lake waters can occur readily as a result of climate changes, resulting in more varied diagenetic potentials within single sequences, compared to marine systems.

Carbonate mudrocks of marine origin have been the focus of a number of studies, which have sought to explain their lithification and mineralogical stabilization. The effects of the stabilization of aragonite muds has been discussed by Steinen (1978, 1982), Lasemi and Sandberg (1984, 1993), Wiggins (1986) and Lasemi et al. (1990). The stabilization process involves the dissolution of aragonite and the precipitation of calcite crystals. Microporosity is created but is lost by cementation and the overgrowth of low-Mg calcite micritic-grade crystals (Saller and Moore, 
1989). The result is a mosaic of micrite, microspar (and pseudospar) crystals, typically anhedral with planar and non-planar crystal boundaries and relict aragonite inclusions or pits (Lasemi and Sandberg, 1984, 1993). Such features have also been produced experimentally from aragonite muds (see discussion in Moshier, 1989a).

The conversion of high-Mg calcite (HMC) muds to low-Mg calcite (LMC) micrites has been discussed by Mazzullo and Bischoff (1992) from subrecent sediments in Belize. The end product of stabilization under near-surface meteoric conditions was also micrite, microspar and pseudospar. Lasemi and Sandberg (1993) have stressed that micrites produced from HMC muds tend to have micritic microfabrics.

Ancient carbonate mudrocks also typically reveal micrite and microspar mosaics of anhedral crystals, with curved or straight crystal boundaries (Moshier, 1989a). Earlier workers regarded such mosaics as evidence of recrystallization, typically of aggrading neomorphism (e.g. Folk, 1965). Other workers have argued that recrystallization without a mineral transformation is not a major process because there is no driving force in mineralogically stabilized micrites (Veizer, 1977; Sandberg and Hudson, 1983; Lasemi and Sandberg, 1984). However, processes may exist to provide such a drive, such as Ostwald's ripening (Morse and Casey, 1988). Chalks, formed initially of LMC particles, are a possible test on the reactivity of low-Mg muds and studies have shown that with burial they tend to lose porosity because of compaction and cementation and overgrowth, but recrystallization is not a significant process (see review in Tucker and Wright, 1990).

The current view appears to be that LMC is stable and micrite-microspar mosaics in ancient limestones most likely represent stabilised aragonitic or high-Mg calcite muds (or both). Lasemi and Sandberg (1993) have listed criteria to distinguish micrites produced from aragonite-dominated precursor (ADP) from calcite-dominated precursor (CDP) muds.

A complication to this apparently simple picture is the occurrence of microporous and commonly microrhombic ancient marine micrites (see volume edited by Handford et al., 1989). These microporous micrites have euhedral or subhedral micro-rhombic to polyhedral calcite crystals ranging in size from 0.5 to $18 \mu \mathrm{m}$ in diameter, with intercrystalline micropores from 2 to $10 \mu \mathrm{m}$ across. The origin of these distinctive fabrics remains unresolved with many authors favouring a HMC precursor, but the suggested diagenetic fluids responsible for the stabilization range from marine, early meteoric, late meteoric to deep burial in origin.

Lacustrine micrites have received very little attention and might be used to identify changes in lake water chemistry using their microfabrics. A variety of micritic-grade carbonates are known from modern freshwater and saline lakes including aragonite, HMC, LMC and dolomite. The nature of the precipitate is dependent on the $\mathrm{Mg} / \mathrm{Ca}$ of the lake waters (Tucker and Wright, 1990). Lacustrine micrites of Late Miocene age in the Madrid Basin, Spain, are highly indurated and the aim of this study was to investigate the causes of lithification of muds which had never been buried more than a few metres. Palaeontological evidence (Sanz et al., 1992) suggested that the shallow lakes were freshwater in composition but evidence presented below points to elevated $\mathrm{Mg} / \mathrm{Ca}$ ratios from which $\mathrm{HMC}$ muds formed.

\section{Geological setting}

The Madrid Basin, located in central Spain (Fig. 1), was filled during the Tertiary by a wide range of alluvial and lacustrine sediments. This intracratonic basin, which has an extent that exceeds $10,000 \mathrm{~km}^{2}$, underwent a rather complex deformational history controlled by the tectonic movements of its margins (De Vicente et al., 1994). These movements controlled sedimentation in the basin and the major disconformities recognized within the Tertiary sequence. Neogene deposits constitute most of the sequences that crop out in the Madrid Basin, while Palaeogene sediments are restricted to outcrops near the basin margins.

The general stratigraphy of the Neogene record has been described by several authors (Junco and Calvo, 1983; Calvo et al., 1989, amongst others) and it is shown in Fig. 2. Within the Miocene three main sedimentary units occur separated by major disconformities (Calvo et al., 1989). The Lower Unit contains lacustrine evaporites and alluvial de- 


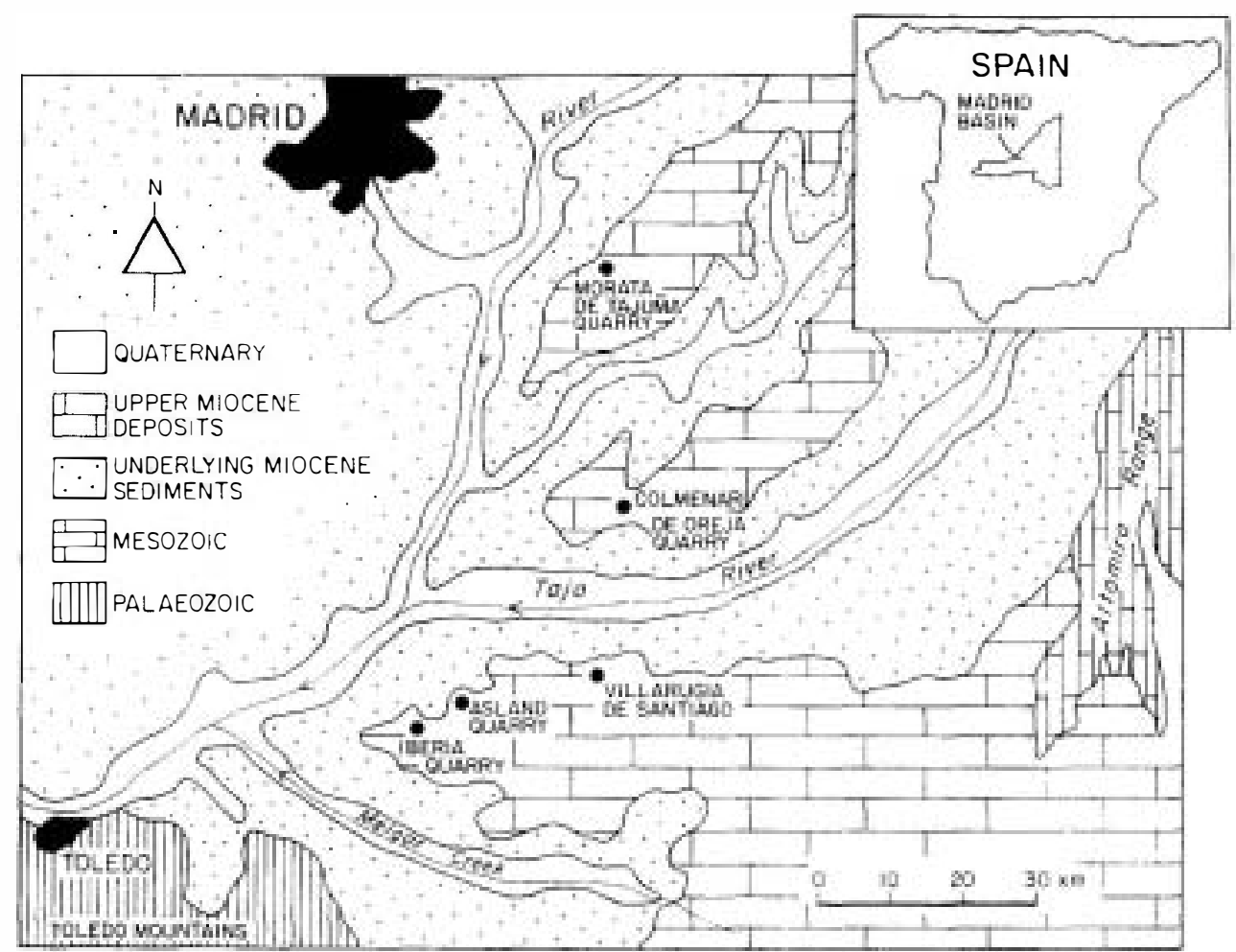

Fig. 1. Location map, showing the study area and the distribution of the Upper Mincene deposits. Location of the main outerops are also shown.

posits (Ordóñez et al., 1991; Rodríguez-Aranda et al., 1991). The Intermediate Unit comprises an alternating sequence of lacustrine carbonates, evaporites and clastic sediments (Calvo et al., 1989; Alonso Zarza et al., 1992, 1993; Sanz et al., 1994). The Upper Unit, up to $50 \mathrm{~m}$ thick, contains red alluvial deposits (Unidad Detrítica del Páramo) and lacustrine carbonates, which are the subject of this paper.

Later exposure resulted in intensive karst development (Fig. 3) in some areas of the basin (Sanz, 1994) and folding of these deposits took place during the Pliocene (Capote and Fernández-Casals, 1978; Pérez-González, 1982). Lake deposits of the Lpper Unit are overlain by red clastic Pliocene sediments and/or a pedogenic laminar calcrete of PlioPleistocene age (Pérez-González, 1982; Sanz and Wright, 1994) which forms the final infill of the Tertiary basin.

The highly indurated lacustrine carbonates analysed in this paper form the uppermost part of the Miocene Upper Unit (Fig. 2), whose age is upper
Turolian. about 5-7 Ma (Sanz et al., 1992). The carbonates were deposited in a complex mosaic of shallow freshwater lakes, probably interconnected by rivers (Fig. 4; Sanz, 1994). They were relatively small lakes whose spatial distribution was controlled by $\mathrm{N}-\mathrm{S}$ lineations (Calvo et al.. 1996). Extensive precipitation of carbonate in the lakes was probably favoured by active leaching of older Miocene carbonates in the basin (Calvo et al., 1989; Cañaveras et al.. 1996).

Within these lakes different lithofacies developed in different environments (Fig. 4). Mudstones and wackestones to packstones constitute the typical open lacustrine deposits. The more restricted fauna, mostly ostracods, of the mudstones may indicate that deposition took place in a slightly deeper environment. probably disconnected of the fluvial systems, while lacustrine wackestones represent shallower environments. Lake margin deposits are represented by tufas and/or oncolitic limestones and palustrine carbonates (in the sense of Freytet, 1984). 

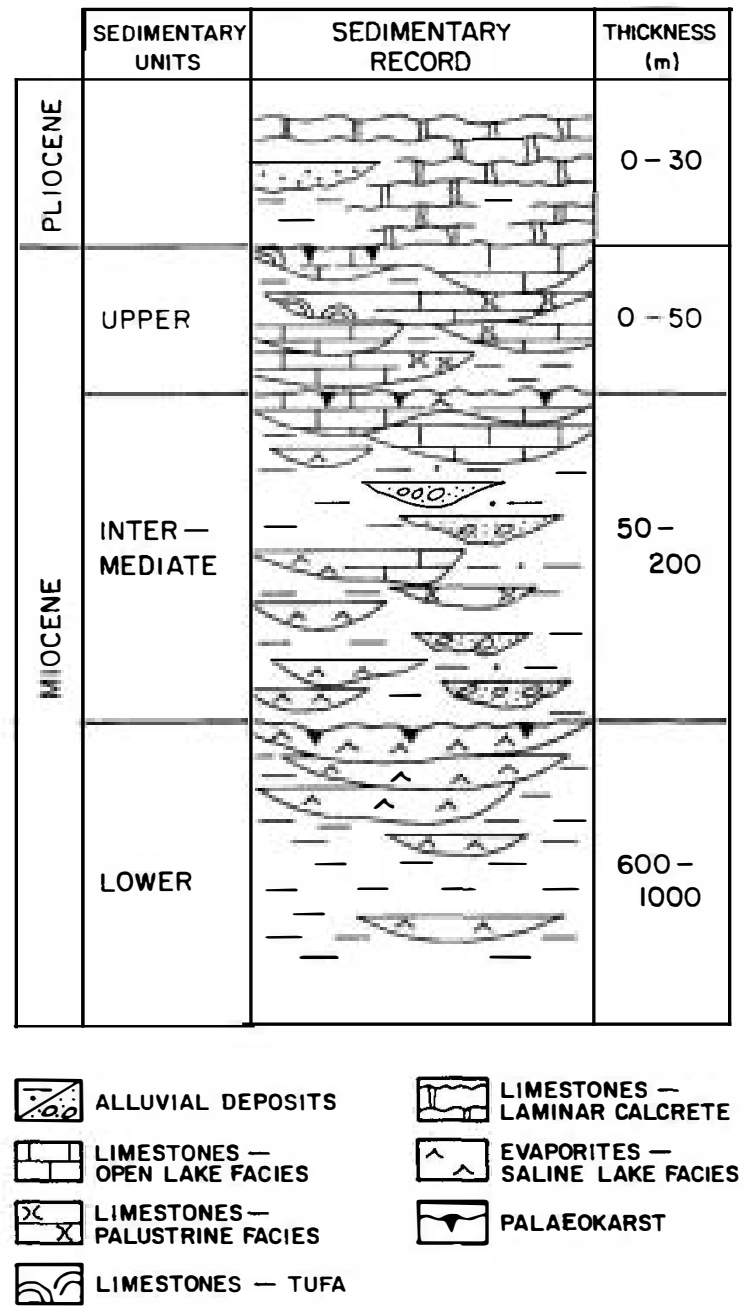

Fig. 2. Stratigraphy of the Neogene sequence of the southern part of the Madrid Basin.

\section{Techniques and methods}

Samples were obtained in five different quarries: Morata de Tajuña, Colmenar de Oreja, Villarrubia de Santiago, Iberia and Asland (Figs. 1 and 4); all of them correspond to lacustrine deposits of the Upper Unit. More than 50 thin-sections were analyzed under transmitted light microscope and about 30 under the cathodoluminoscope (CL) (Technosyn).

Scanning electron microscopy was carried out on a JEOL JSM-6.400 working on $20 \mathrm{kV}$, using fracture and polished and etched surfaces covered with gold. Polished thin-sections were treated with $0.2 \%$ formic acid and etched for 7-10 s. Crystal size determinations were made using SEM photomicrographs. $\mathrm{C}$ and $\mathrm{O}$ stable isotope samples were prepared by drilling from pre-selected areas and analyzed on a V.O. SIRA Series II Mass spectrometer following reaction with $100 \%$ phosphoric acid. Acid residues used for major and trace element were analysed by ICP. Porosity measurements were made using a mercury porosimeter and measurements of pore sizes were made using SEM photomicrographs.

\section{Petrography of the lake carbonates}

Three associations of micritic limestones have been noted, each with distinctive petrographic features, and all the studied muds show a lack of pelletal structure.

\subsection{Lacustrine mudstones}

Lacustrine mudstones have been studied in the Arroyo del Tesoro area, near the Asland Quarry. They occur in two beds each approximately $1 \mathrm{~m}$ thick. In outcrop they are grey in colour and are highly indurated. They are structureless and the main bioclasts are ostracods, although some charophyte gyrogonites are present. The micrite matrix is rather homogeneous and dense. Some dissolution vugs as well as the intraparticle porosity have been filled by calcite spar. No evidence for compaction has been found (Fig. 5A). Locally some lenticular gypsum moulds occur within the micrite, but are not common. The moulds are also filled by calcite spar (Fig. 5B).

Under the CL the micrite is all non-luminescent as are the spar mosaics and the gyrogonites. The only luminescent particles in these limestones are ostracods whose shell structure is well preserved.

Under the SEM the limestones consist of a mosaic of anhedral crystals (xenotopic mosaic) (Fig. 6A and Fig. 7A) in which the average crystal size is $1.22 \mu \mathrm{m}$ (Fig. 8), with a standard deviation of 0.41 . Within the mosaics there is no grading or ordering in size and morphology of the crystals, the larger ones $(>1.8$ $\mu \mathrm{m}$ ) being distributed irregularly with smaller ones. The crystals are embayed and show interlocked grain boundaries. No aragonite relics or solution pits after acicular crystals, or microdolomite inclusions, have 


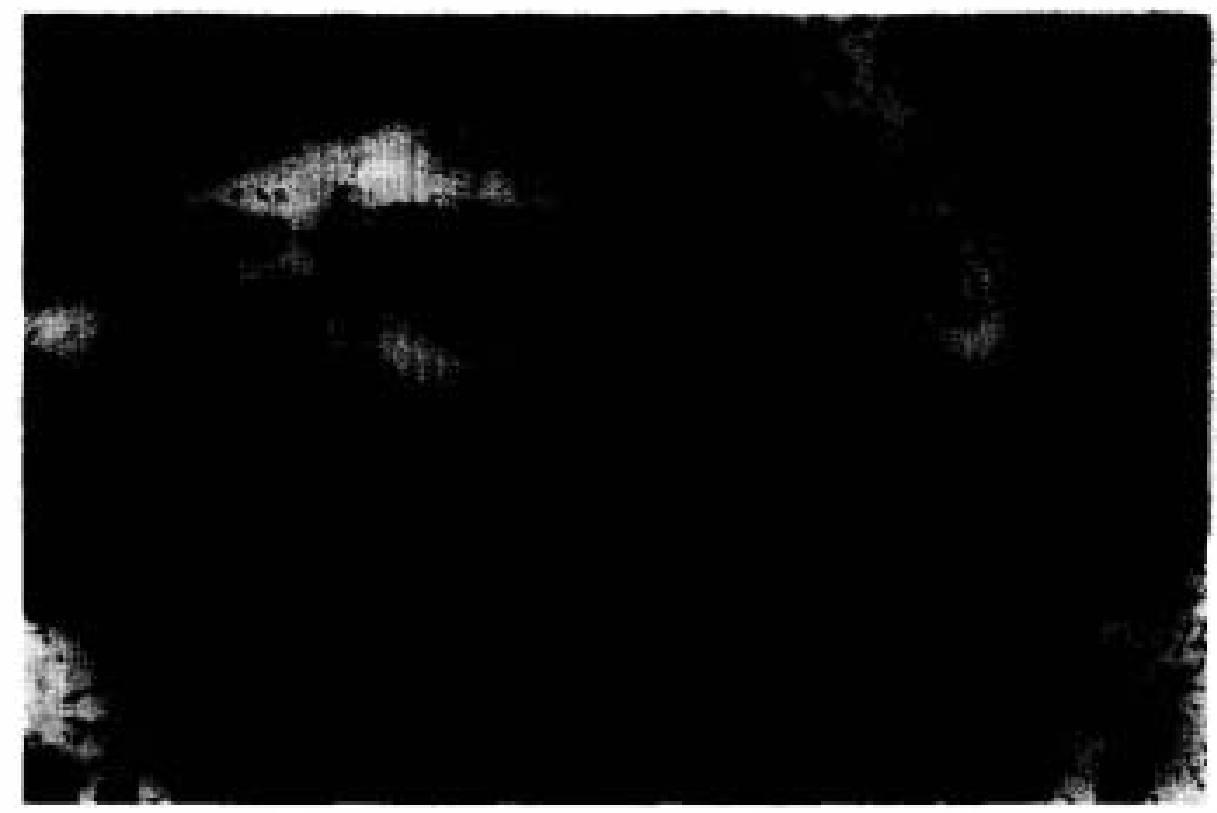

Fig. 3. Outcrop views of karst effects on the Upper Unit. Ocaña-Hispania Quarry. Note intensive piping.

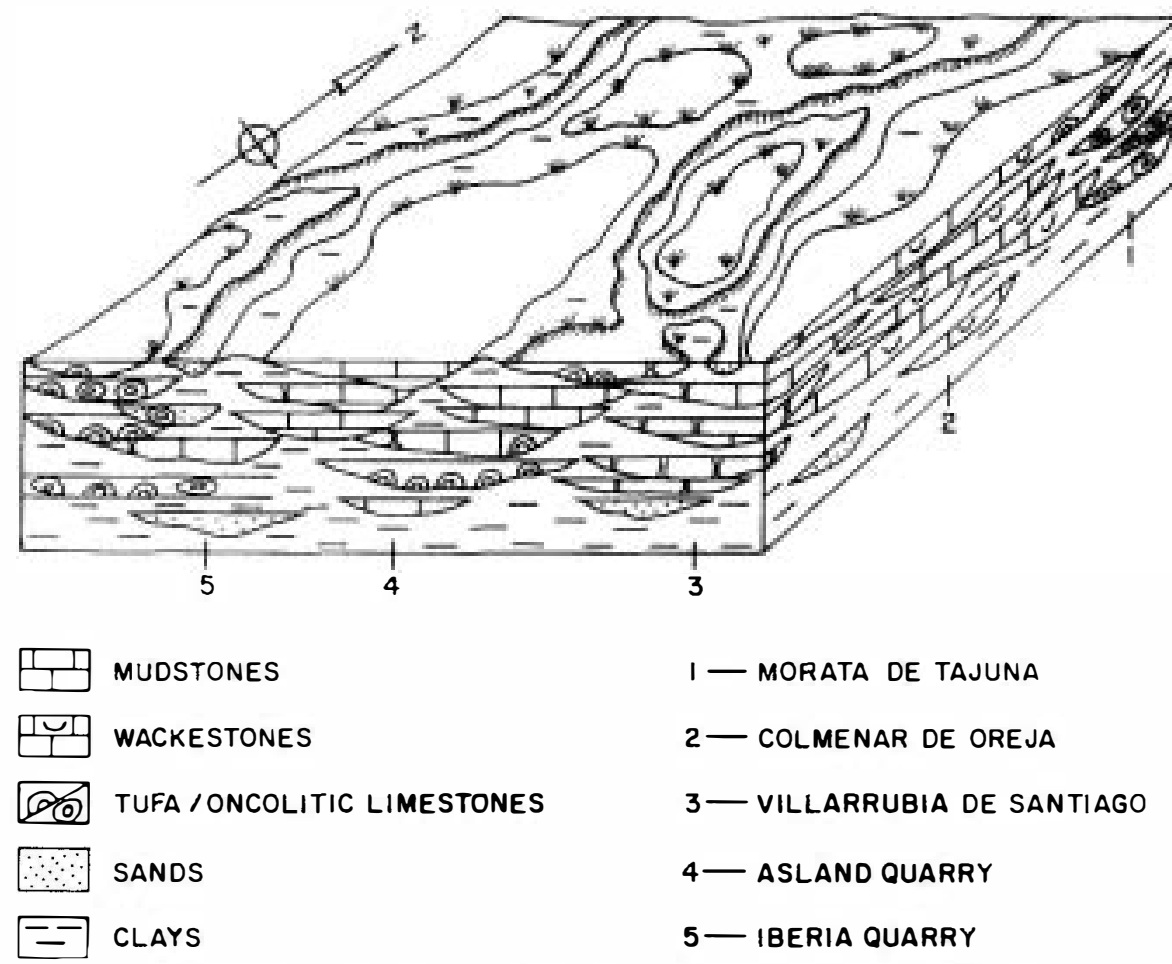

Fig. 4. Schematic representation of the depositional systems during the deposition of the Upper Unit in the south of the Madrid Basin. 


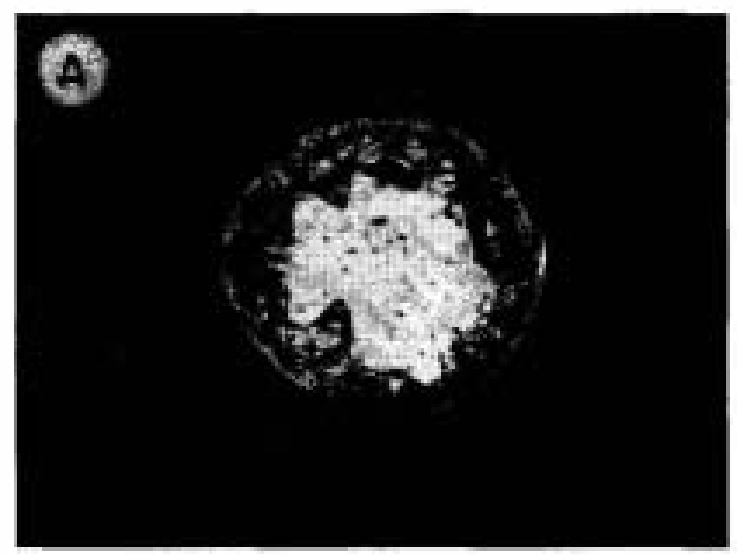

$\longmapsto 0.1 \mathrm{~mm}$

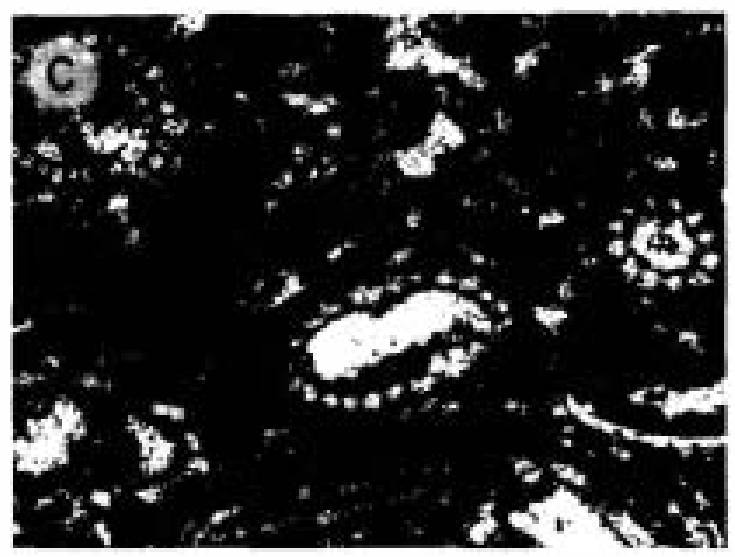

$\longmapsto 0.25 \mathrm{~mm}$
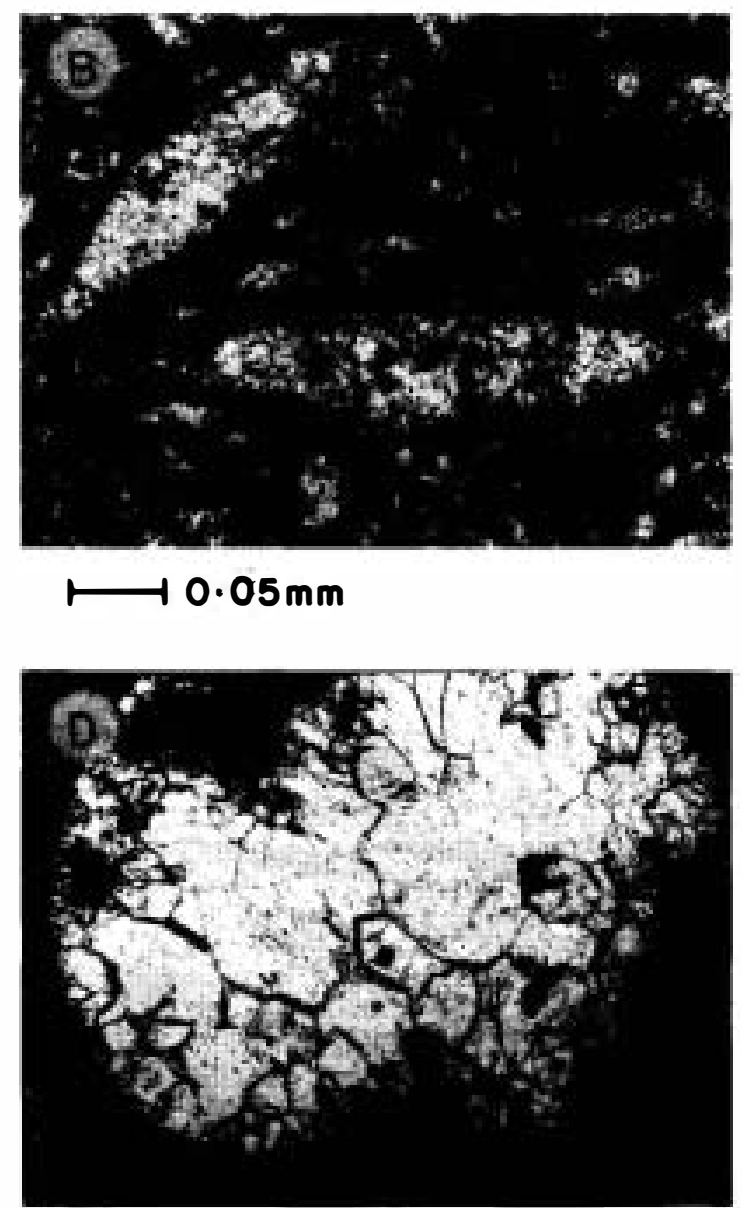

$\longmapsto 0.25 \mathrm{~mm}$

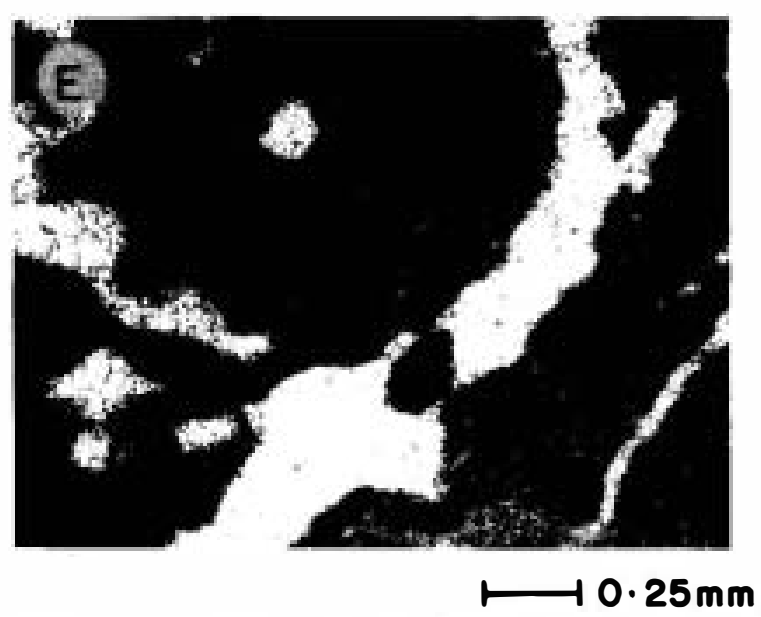

Fig. 5. Photomicrographs of the lacustrine carbonates of the Upper Unit. (A) Lacustrine mudstone, in which the ostracod does not show any evidence of compaction. (B) Gypsum pseudomorphs filled by a late calcite spar cement; as in (D) the cement is non-luminescent. (C) Lacustrine wackestone/packstone containing charophyte bioclasts. (D) Cavity infilled by late calcite spar. (E) Palustrine limestones consist of a dense groundmass of micrite which is heavily disrupted by desiccation cracks. 
been noted in these limestones or in any others in this study.

Porosity is rather low in these samples, averaging $3 \%$. Two main types of pores are present: (a) intercrystalline, rather irregular micropores averaging 0.5 $\mu \mathrm{m}$ in size, and (b) intracrystalline rhombic pores which occur mainly on the surface of the calcite crystals. Mean size of these micropores is about 0.2 $\mu \mathrm{m}$.

\subsection{Lacustrine wackestones (and packstones)}

These are the most typical facies of the Upper Unit. They have been studied mainly in the Colmenar de Oreja Quarry, where they are exploited for building. The quarry is formed by more than seven different beds whose total thickness is about $15 \mathrm{~m}$.

The bioclasts consist of charophyte stems and gyrogonites as well as ostracods. The charophyte bioclasts are not preserved in their normal spar-grade carbonate, but as micrite (Fig. 5C), which has the same appearance as the micrite matrix in ransmitted light and is brightly luminescent under the CL. Evidence for micritization is clear as much of the micrite matrix, featureless under transmitted light, is seen to contain ghosts of bioclasts (mainly charophyte fragments) under the CL. In some areas the micrite is seen to have been replaced by micro-pseudospar (approximately $10 \mu \mathrm{m}$ in size). In these areas the bright luminescence is absent. The ostracods are luminescent and their original shell structure seems to be well preserved. As in the lacustrine mudstones there is no evidence that the rock has undergone compaction. Intraparticle porosity is usually filled geopetally by luminescent micrite and non-luminescent calcite spar (Fig. 5D). Calcite spar also fills dissolution voids. Gypsum pseudomorphs occur locally, which consist of a single calcite crystal; these crystals also show bright luminescence.

Under the SEM the carbonates are formed by a porous loosely packed mosaic or framework (Fig. 7B) of euhedral to subhedral crystals, in which their initial rhombic morphology is often preserved (Fig. 6B,C). Average size of the crystals is $1.08 \mu \mathrm{m}$ with a standard deviation of 0.55 , and the larger crystals of about $3 \mu \mathrm{m}$ size (Fig. 8). These smaller micrite crystals form the framework. Microsparpseudospar crystals are typically euhedral (Fig. 6B and Fig. 7B). They are distributed irregularly within the micrite and within the bioclasts. The crystal faces locally show dissolution features. As in the mudstones and palustrine limestones, no relict aragonite needles or solution pits after acicular precursors, or microdolomite inclusions have been seen in polished samples (Fig. 6E). The packing of the micro-pseudospar crystals is denser than that observed in the micrite.

Porosity in these lacustrine limestones is also low, averaging $2 \%$, but is locally much higher and consists mainly of three types.

(a) Irregular and/or elongated vugs of 3-5 $\mu \mathrm{m}$ size.

(b) Intercrystalline pores of very irregular morphology whose size is about 1 to $0.5 \mu \mathrm{m}$.

(c) Rhombic intracrystalline pores less than $1 \mu \mathrm{m}$ in size. This type of porosity mainly occurs in the smaller and more euhedral crystals, and is absent in the more coarsely crystalline areas.

\subsection{Palustrine limestones}

Palustrine limestones occur in most of the studied sections mainly at the base of the lacustrine succession. They appear as massive, 1 to $2 \mathrm{~m}$ thick beds which show yellow mottling and a wide variety of desiccation cracks ranging from planar to circumgranular (Fig. 5E). The palustrine limestones consist of mudstones which include variable amounts (less that $10 \%$ ) of detrital quartz, feldspar and some bioclasts. Bioclasts are mainly fragments of ostracods and charophyte debris.

The micrite matrix is typically dense and dark. Under the CL two different situations have been observed: luminescent and non-luminescent micrite, but never in the same sample. Luminescent micrite is quite similar to the micrite that forms the wackestone lacustrine deposits, but in this case it is brecciated and disrupted by desiccation cracks. Some bioclast ghosts have also been identified under the CL. Non-luminescent micrite occurs in the more homogeneous, less brecciated and mottled palustrine deposits, which are similar to the mudstone facies.

Microspar occurs irregularly distributed through the micrite groundmass as well as at the contacts between the micrite fragments and the cracks. It is non-luminescent. It differs from late spar cements 

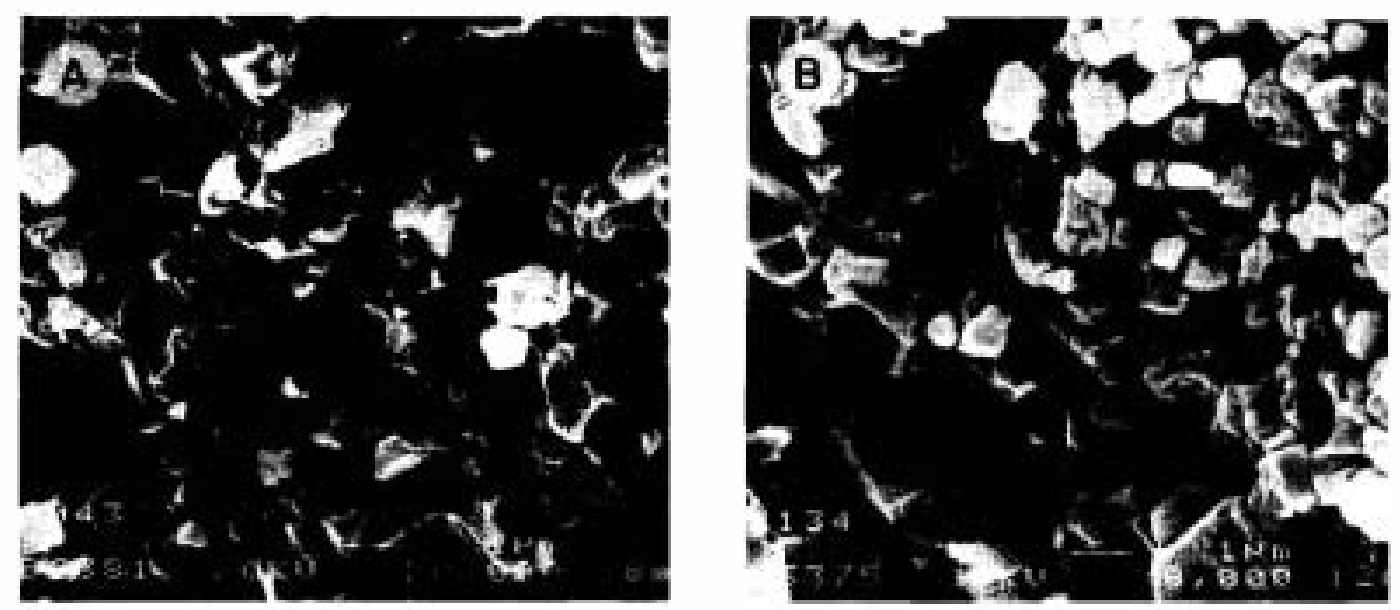

$\longmapsto$ I

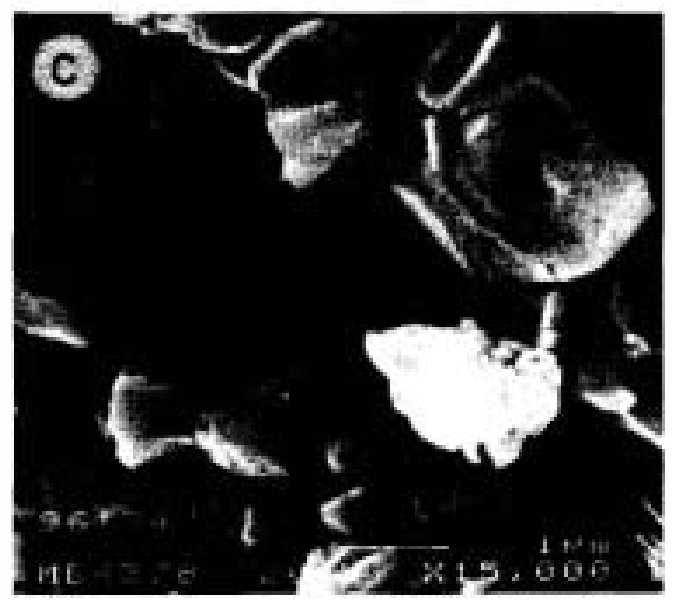

$\longmapsto$

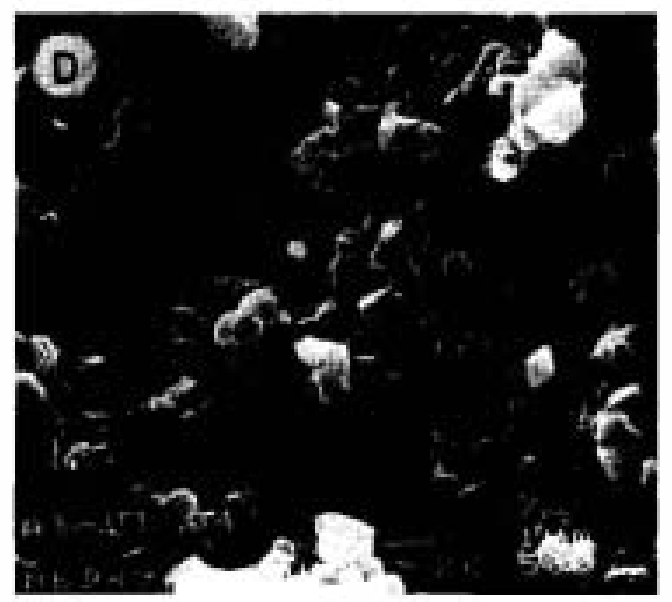

$\longmapsto 1$ I m

f) 

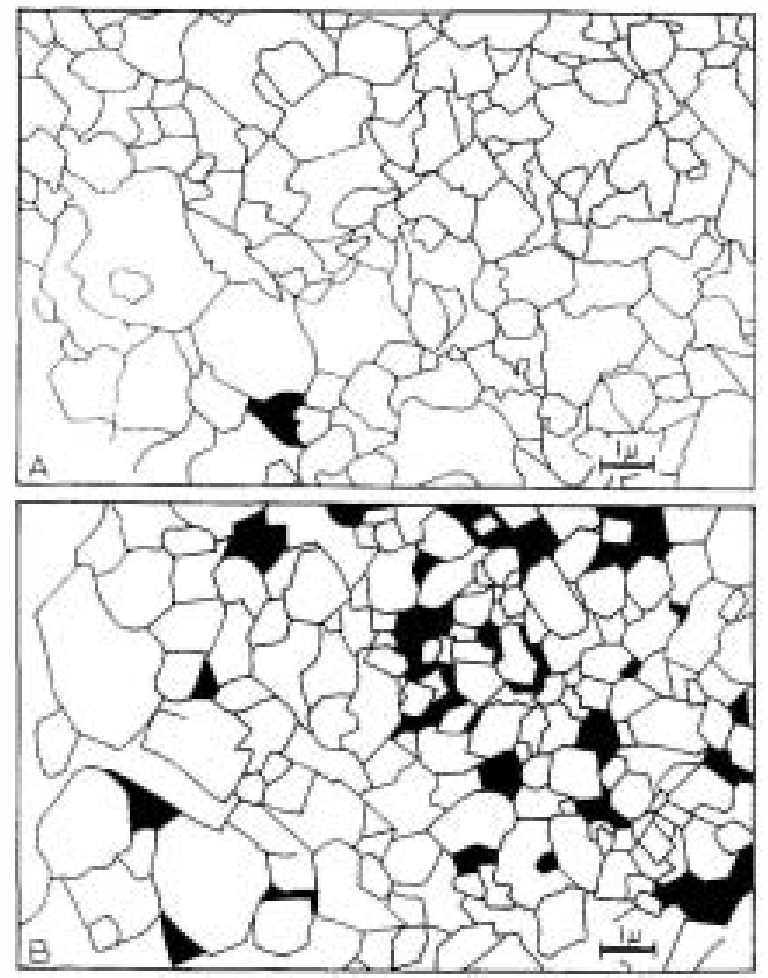

Fig. 7. Sketch of the different types of micritic mosaics recognized in the lacustrine carbonates: (A) anhedral mosaics; (B) microporous crystal frameworks. Black areas represent porosity. Drawn from SEM photomicrographs of polished slides.

which fill the desiccation cracks as these cements consist of mosaics of spar which are locally seen to be zoned under the CL.

Under the SEM the palustrine samples show a wide variety of textures. All of them are quite fine crystal mosaics (Fig. 6D; average $0.9 \mu \mathrm{m}$, standard deviation 0.3 ). Crystal morphologies vary from euhedral to anhedral even within the same sample. Porosity types include the previously mentioned ones:

(a) intercrystalline pores, of about $0.5 \mu \mathrm{m}$ in size, which are more frequent in subeuhedral to anhedral mosaics; (b) irregular and elongated vugs, whose size is very variable;

(c) rhombic pores on the surface of calcite crystals; typical of more euhedral mosaics of the more homogeneous palustrine deposits.

\section{Geochemical analyses}

Samples were analysed for $\mathrm{C}$ and $\mathrm{O}$ stable isotopes and for major and trace element composition. The results are shown in Table 1. Fig. 9a shows a cross-plot of $\mathrm{Mg}$ and $\mathrm{Sr}$ values showing a strong covariance. Fig. $9 \mathrm{~b}$ is a plot of isotopic composition

Table

Geochemistry of lacustrine carbonates

\begin{tabular}{|c|c|c|c|c|c|}
\hline $\begin{array}{l}\mathbf{M g} \\
(\mathrm{ppm})\end{array}$ & $\begin{array}{l}\mathrm{Fe} \\
(\mathrm{ppm})\end{array}$ & $\begin{array}{l}\text { Mn } \\
(\mathrm{ppm})\end{array}$ & $\begin{array}{l}\mathrm{S} r \\
(\mathrm{ppm})\end{array}$ & ${ }^{18} \mathrm{O}$ & ${ }^{13} \mathrm{C}$ \\
\hline \multicolumn{6}{|c|}{ Lacustrine mudstones } \\
\hline 2905 & 2143 & 49 & 455 & -6.08 & -7.79 \\
\hline 2569 & 2378 & 14 & 497 & -6.02 & -8.15 \\
\hline 2824 & 1500 & 37 & 440 & -5.56 & -6.72 \\
\hline 2291 & 897 & 304 & 403 & -5.88 & -7.67 \\
\hline 2452 & 551 & 12 & 472 & -6.34 & -8.05 \\
\hline \multicolumn{6}{|c|}{ Lacustrine wackestones } \\
\hline 1976 & 1765 & 33 & 276 & -5.65 & -6.72 \\
\hline 1935 & 1536 & 29 & 195 & -6.13 & -7.29 \\
\hline 2470 & 3951 & 95 & 606 & -6.13 & -8.03 \\
\hline 2036 & 1657 & 22 & 434 & -6.14 & -7.01 \\
\hline 1408 & 293 & 30 & 243 & -5.29 & -6.67 \\
\hline 1552 & 271 & 6 & 302 & -5.89 & -7.67 \\
\hline 1527 & 166 & 27 & 243 & -5.51 & -6.73 \\
\hline 1453 & 364 & 24 & 215 & -5.73 & -6.73 \\
\hline \multicolumn{6}{|c|}{ Palustrine limestones } \\
\hline 4651 & 2552 & 92 & 304 & -4.96 & -7.18 \\
\hline 2961 & 770 & 55 & 807 & -4.58 & -8.06 \\
\hline 2032 & 5539 & 45 & 331 & -5.12 & -7.59 \\
\hline \multicolumn{6}{|c|}{ Spar cements } \\
\hline 988 & 354 & 57 & 167 & -5.61 & -8.07 \\
\hline 1011 & 172 & 15 & 56 & -7.14 & -9.06 \\
\hline 1518 & 110 & 22 & 248 & -6.94 & -9.09 \\
\hline 451 & 5 & 49 & 60 & - & - \\
\hline
\end{tabular}

Fig. 6. SEM photomicrographs. (A) The anhedral mosaics in the lacustrine mudstones are formed by very fine calcite crystals $(<1 \mu \mathrm{m})$, no grading or ordering can be detected. (B) Lacustrine wackestones are formed by loosely packed mosaics of euhedral to subhedral calcite crystals (upper right segment), with microspar crystals in the lower left segment. (C) Detailed view of the euhedral micrite crystals that form the microporous crystal frameworks. (D) General view of the aspect of some palustrine facies, the arrangement and distribution is very similar to that of the lacustrine wackestones. (E) Polished and etched section of anhedral mosaic from lacustrine mudstone. 
A- MUDSTONES

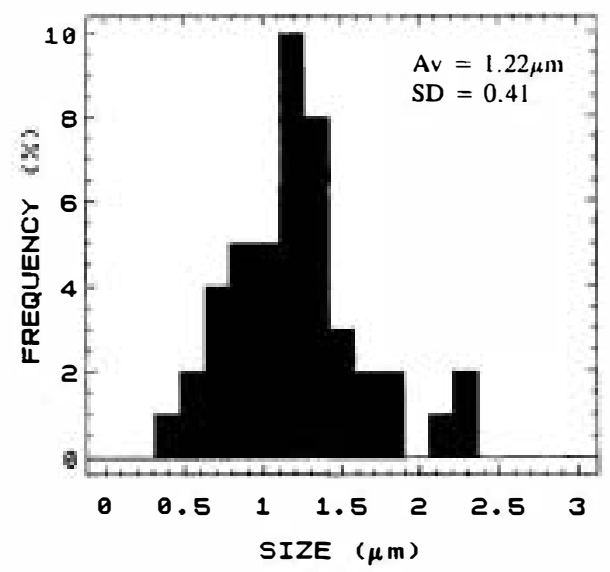

B-WACKESTONES

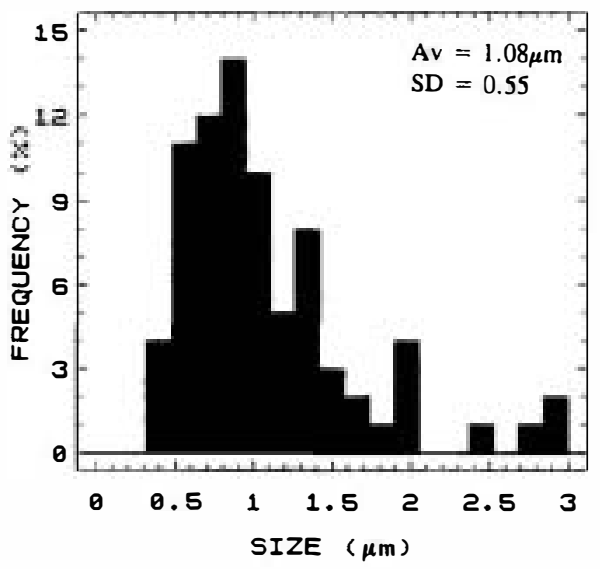

C- PALUSTRINE

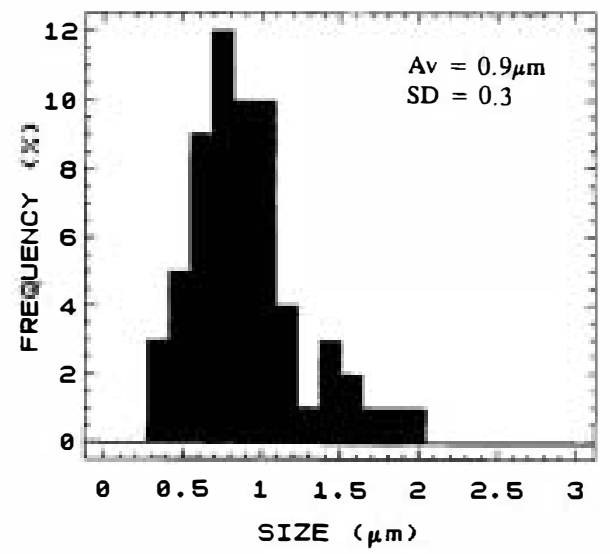

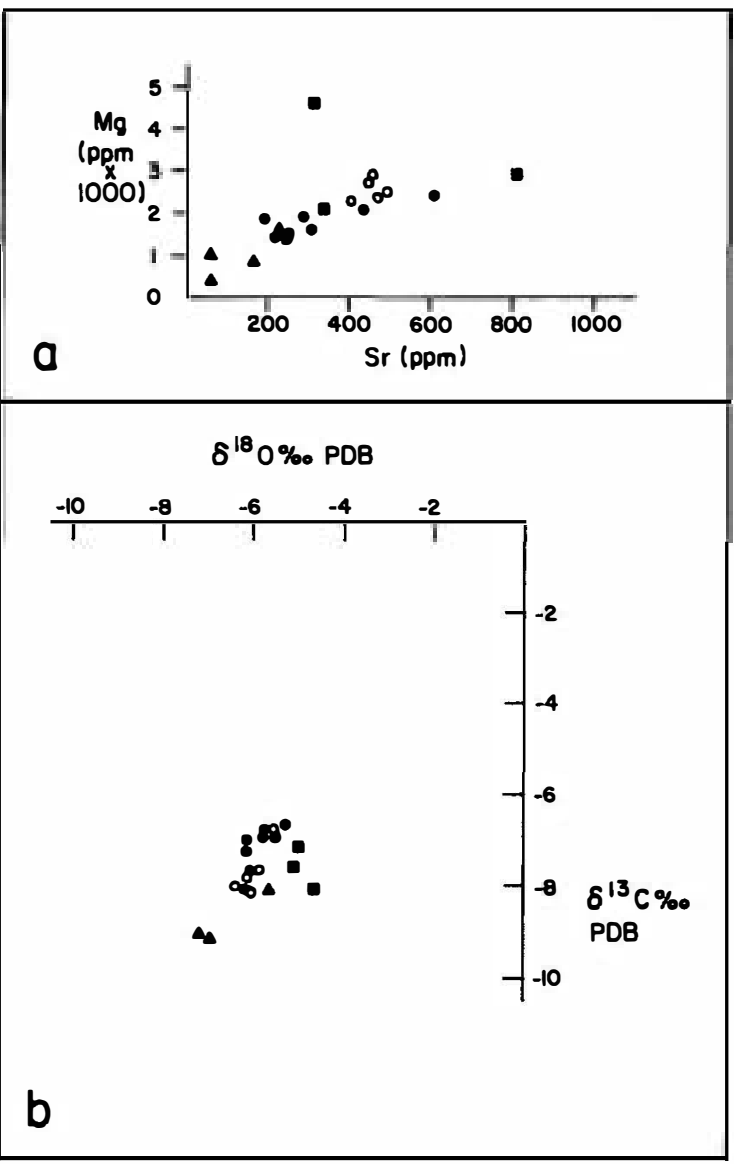

- Locustrine mudstones - Locustrine wockestones

- Polustrinelimestones $\Delta$ Spor cement

Fig. 9. (a) Magnesium-strontium covariant plot of the different lacustrine facies. The values for calcite spar cements are also shown. (b) Stable oxygen and carbon isotope compositions of the limestones and the cements.

of the micrites, and spar cements. The similarities of the isotope values from different depositional settings are discussed below.

\section{Interpretation}

Despite the variety of textures, two basic micrite types occur: anhedral mosaics (Fig. 7A) occur

Fig. 8. Crystal size plots of: (A) lacustrine mudstones; (B) lacusrine wackestone/packstones; (C) palustrine limestone. Number of crystals measured for each plot $=100$. Determined from measurements on SEM photomicrographs. 
in the lacustrine mudstones, and some palustrine limestones; locally microporous crystal frameworks (Fig. 7B) occur in the wackestones and in palustrine limestones.

Some components appear to be in an unaltered state such as the ostracod caparaces and some encrustations on charophyte stems. In the case of the latter two forms the well defined prismatic crystals do not display any features indicative of replacement. The following discussion concentrates on the micritic carbonates.

The fabrics seen in the lacustrine and palustrine limestones are regarded as the products of recrystallization. We base this interpretation on the absence of any distinct particles which could be interpreted as primary (depositional) mud-grade material. Relatively little has been published on the morphology of lacustrine carbonate muds but micritic and coarser polyhedra have been recorded from hard water lakes (Kelts and Hsü, 1978). Pedley (1992) has reviewed the common types of micrite in freshwater tufas and none of the mechanisms discussed in the production of freshwater micrite appear capable of producing the fabrics seen in these Miocene carbonates. Of particular significance is the fact that these Miocene limestones exhibit no fabrics resembling cyanobacterial tubules, coccoid chains or rods, clotted 'aggregates' or the irregular micrite forms found associated with biofilms described by Pedley (1992).

\subsection{Anhedral mosaics}

The dense, interconnected mosaics recorded in these lacustrine mudstones and palustrine limestones resemble ancient marine micritic limestones (e.g. see Moshier, 1989a; Tucker and Wright, 1990). There are two possible explanations for the origin of these mosaics: firstly, they could have formed by the recrystallization of LMC muds, or secondly, they represent the replacement of metastable muds.

If these mosaics resulted from the recrystallization of LMC muds a problem arises as regards a mechanism (diagenetic drive) for that recrystallization. If the micrites replaced a metastable aragoniterich precursor mud there is now a complete absence of aragonite relics or solution holes attributable to aragonite. The anhedral mosaics differ from those found in replaced Pleistocene marine aragonite muds documented by Lasemi and Sandberg (1993), which are much coarser (average $7 \mu \mathrm{m}$ ) and more variable in crystal size (standard deviation of 3.3) than these Miocene examples. Lasemi and Sandberg (1984) noted that stabilised Pleistocene aragonitedominated muds had 1800-1900 ppm Sr and 2000$1400 \mathrm{ppm} \mathrm{Mg}$. Furthermore, Lasemi and Sandberg (1993) suggested that micrites formed from aragonite-dominated precursor (ADP) muds should have Sr values of $>800 \mathrm{ppm}$, with calcite-dominated precursor (CDP) muds having mean values of $400 \mathrm{ppm}$. The low $\mathrm{Sr}$ values of these anhedral mosaic micrites suggests that the precursor muds were not aragonite dominated. Lacustrine aragonite muds have been found preserved in Oligocene carbonates from the Campïns Basin of northeast Spain by Anadón and Utrilla (1993).

The similarities between the anhedral micrites and replaced HMC muds are stronger. CDP micrites have average crystal sizes of $2.4 \mu \mathrm{m}$ and are less variable in crystal size range (standard deviation of 1.2; Lasemi and Sandberg, 1993). Possible stabilised HMC micrites of Pliocene age documented by Lasemi and Sandberg (1984) had values of 4700 ppm $\mathrm{Mg}$ and $400 \mathrm{ppm} \mathrm{Sr}$. Relatively recently stabilised high-Mg-dominated muds from Belize described by Mazzullo and Bischoff (1992) had $\mathrm{Sr}$ values of $1300 \mathrm{ppm}$ and over 2 mole\% $\mathrm{MgCO}_{3}$. Some of the $\mathrm{Mg}$ concentrations in the palustrine limestone average $1700 \mathrm{ppm}$ and reach $5000 \mathrm{ppm}$, and in the mudstones the mean $\mathrm{Mg}$ value is 2737 ppm. Modern calcitic muds of the Everglades, with $<2 \%$ mole $\mathrm{Mg} \mathrm{CO}_{3}$ have $\mathrm{Sr}$ values in the range 510-1190 ppm (Andrews, 1991).

Fig. 9a shows a plot of the $\mathrm{Mg}$ and $\mathrm{Sr}$ values, and a strong covariance exists. Moshier (1989b, fig. 21) presented $\mathrm{Mg}-\mathrm{Sr}$ covariant plots showing fields for various types of marine muds. Assuming the proportionality of these two elements has not changed during diagenesis, the trend of covariance for the lacustrine micrites might correspond to an original aragonite-Mg calcite-calcite mixture, if extrapolated to higher concentrations, and allowing for loss during diagenesis. Whether these assumptions and extrapolations are valid is open to question but the covariant trend is distinctive. Interestingly the late meteoric spar cements show a weaker correlation with this trend. Covariant trends in $\mathrm{Sr}$ and 
Mg are a characteristic of marine HMC (Major and Wilber, 1991; Carpenter and Lohmann, 1992) and have been noted in ancient micrites interpreted as of CDP origin (Z. Lasemi, pers. commun., 1995).

The isotopic values display considerable overlap but with a strong meteoric signature, with no evidence of any values indicating elevated salinities in the original fluids from which they precipitated. These values most likely represent lithification under meteoric conditions associated with Pliocene karstification.

\subsection{Microporous crystal frameworks}

The fine, relatively uniform crystal size of these micrites is comparable to that found in presumed CDP micrites (see above; Lasemi and Sandberg, 1993). These micrites also lack aragonite relics or pits and have $\mathrm{Sr}$ values on average below $400 \mathrm{ppm}$ (with some exceptions, Table 1). The replacement of various skeletal grains by these Miocene micrites is evidence of a replacement origin. The euhedral to subhedral form and uniformity of crystal size also suggests a secondary origin. The micritisation of charophyte gyrogonites is unusual for these are normally low-Mg calcites, although high-Mg calcites have been found in charophyte gyrogonites in some saline lakes (Burne et al., 1980). The uniform luminescence, including the similar luminescence seen in replaced bioclasts, suggests that the precipitation of the mosaics took place under sub-oxic conditions. The amounts of $\mathrm{Mn}$ present are low (>50 ppm) but the micrites also have low $\mathrm{Fe}$ contents preventing quenching (Savard et al., 1995). These micrites also have the lowest $\mathrm{Mg}$ and $\mathrm{Sr}$ contents (Table 1). Their $\mathrm{C}$ and $\mathrm{O}$ isotope values overlap with those of the anhedral mosaics and indicate a strong meteoric signature.

These frameworks are also similar to those described from a number of marine limestones (see case studies in Handford et al., 1989). However, there are some differences between these porous frameworks and 'classical' marine micro-rhombic, microporous micrites. The latter typically have crystal sizes in the 4-8 $\mu \mathrm{m}$ range (Moshier, 1989a) whereas those in this study largely fall in the range $0.5-1.5 \mu \mathrm{m}$. Pore sizes in marine-derived microporous micrites are typically $5-10 \mu \mathrm{m}$ wide but those here are $0.5-5 \mu \mathrm{m}$ in size. Little agreement exists on the origins of such crystal frameworks but their derivation from metastable precursor sediments is generally accepted. Previous studies of microporous crystal frameworks in marine limestones have invoked the action of a range of diagenetic settings and fluids including marine fluids, and alteration in deep burial settings (e.g. Saller and Moore, 1989; Dravis, 1989). Moshier (1989b) and Saller and Moore (1989) have provided detailed geochemical data for marineprecursor microporous micrites from the Cretaceous of the Middle East and Oligocene of the Pacific, respectively. In both these cases the trace element contents for both $\mathrm{Mg}$ and $\mathrm{Sr}$ are much lower than those described here, although not higher in some cases than for the anhedral mosaics. These framework micrites also display a covariance of $\mathrm{Mg}$ with $\mathrm{Sr}$, possibly supporting the idea of a metastable, probably HMC-rich precursor (Fig. 9; see above).

Moshier (1989a) has speculated that the preservation of porosity in microporous micrite crystal frameworks is due to cementation having been inhibited. He regards this as reflecting rather closed diagenetic systems with a high rock/water ratio, isolated from external sources of carbonate. The evidence from these Miocene micrite frameworks is that the micrites are replacive and formed in sub-oxic meteoric waters, probably in a relatively closed system. If a closed system is invoked the original precursor carbonates must also have had very low $\mathrm{Sr}$ and $\mathrm{Mg}$ values. Budd (1989), describing Cretaceous micrites from the Middle East, invoked a two-stage process, whereby stabilisation of metastable marine carbonates took place in a relatively open system, resulting in the flushing of $\mathrm{Sr}$ and $\mathrm{Mg}$, followed by calcitecalcite recrystallization in a more confined diagenetic system, producing the microporous micrites.

In conclusion these frameworks have formed as a result of the replacement probably in a somewhat closed, sub-oxic setting. The lack of aragonite relics or pits, low $\mathrm{Sr}$ content, covariant $\mathrm{Mg} / \mathrm{Sr}$ and fine, relatively uniform fabric all suggest a HMC-rich precursor.

\section{Discussion}

If any metastable carbonate muds had been present they may have resulted from elevated $\mathrm{Mg} / \mathrm{Ca}$ 
in the lakes. $\mathrm{C}$ and $\mathrm{O}$ stable isotopes in carbonates can be used to identify trends in lake hydrology (Talbot, 1990), such as increasing evaporation which can lead to salinity changes and the formation of metastable precipitates (Müller et al., 1972). The occurrence of minor gypsum at some levels is evidence of moderate salinities although metastable carbonates can form in relatively dilute waters if high $\mathrm{Mg} / \mathrm{Ca}$ are achieved (Eugster and Kelts, 1983). However, the isotopic analyses of the carbonates (Fig. 9b) does not indicate any prominent covariant trend of $\mathrm{O}$ and $\mathrm{C}$ as is seen when precipitation of carbonate has occurred during evaporative concentration of lake waters. If, however, stabilisation had taken place during the phase of karstification during the Pliocene, these primary isotopic trends could have been lost. Further support for extensive re-setting of the isotopic values comes from the absence of any distinct trend between the lacustrine mudstones and palustrine micrites. It is common for there to be a trend for increased lighter isotope values between such carbonates reflecting the influence of pedogenic processes (Platt, 1989), which is normally seen in the Miocene carbonates of the Madrid Basin (Wright and Alonso Zarza, 1992).

Why two different micrite types should have formed in these Miocene limestones is unclear. The crude facies control on their distribution suggests some original environmental influence but the sample size we have used is too small to allow any generalizations to be made. Anadón and Utrilla (1993) noted facies-related variations in mineralogy in Oligocene lake carbonates in Spain, as well as stratigraphic variations linked to probable changes in lake hydrology. The most likely explanation is that the two precursor muds had somewhat different compositions. Compositional heterogeneity may be a characteristic of lacustrine micrites reflecting rapid lateral facies changes and the variability in mineralogy of precipitates, both a consequence of the dynamic nature of shallow lake systems. Whereas the presence of microspar in the anhedral mosaics might imply a more aragonite-rich precursor, there is no direct evidence from the presence of aragonite relics, despite their slightly elevated $\mathrm{Sr}$ contents.

One of the original aims of this study was to establish why these limestones were so highly indurated. The explanation seems to be that exten- sive replacement took place, probably in two somewhat different diagenetic systems, associated with meteoric fluids, exposure and karstification in the Pliocene.

The anhedral micrites formed in somewhat more 'open' system without the formation of sub-oxic conditions and with the more extensive addition of carbonate as cement. The microporous crystal frameworks may have developed in a system with a lower water/rock ratio and under sub-oxic conditions. Both micrites probably represent replacements of metastable carbonate muds, but extensive meteoric diagenesis appears to have re-set any original stable isotopic ( $\mathrm{C}$ and $\mathrm{O})$ signatures.

\section{Conclusions}

Miocene continental carbonates in the Madrid Basin have undergone complex diagenetic alteration which suggests that they may have originally contained metastable carbonate muds. Two types of micrite are present. One consists of anhedral mosaics and the second type consists of locally microporous, micro-rhombic micrites. Both types resemble fabrics found in micritic marine limestones. The lack of aragonite relics or pits, low $\mathrm{Sr}$ content and the covariance of $\mathrm{Mg}$ and $\mathrm{Sr}$ suggest a probable HMC-rich precursor. The $\mathrm{O}$ and $\mathrm{C}$ stable isotopic values indicate stabilisation under meteoric conditions, which probably overprinted primary environmental signatures. The causes of the variations in micrite fabric. which partly correlate with depositional facies, is unclear.

Criteria used to identify the original compositions of ancient marine micrites can be applied to lacustrine carbonates and can provide information on the chemistry of ancient lakes, complementing geochemical and palaeontological criteria.

\section{Acknowledgements}

This work was made possible through a BritishSpanish Joint Research Programme Acciones Integrades grant. Mike Isaacs, Ivan Edwards and Salim Malik are thanked for the geochemical analyses. Alan Cross, Deborah Whitmore and Jill Banham helped prepare the illustrations and text. We especially thank Zakaria Lasemi for many insightful 
comments on an earlier version of this paper. Steve Moshier and Axel Munnecke are thanked for their constructive reviews of the manuscript. PRIS Contribution number 592 .

\section{References}

Alonso Zarza, A.M., Calvo, J.P., Garcia del Cura, M.A., 1992. Palustrine sedimentation and associated features grainification and pseudo-microkarst -in the middle Miocene (Intermediate Unit) of the Madrid Basin, Spain. Sediment. Geol. 76, 43-61.

Alonso Zarza, A.M., Calvo, J.P., Garcia del Cura, M.A., 1993. Palaeogeomorphological controls on the distribution and sedimentary styles of alluvial systems, Neogene of the NE of the Madrid Basin (central Spain). Spec. Publ. Int. Assoc. Sedimentol. 17, 277-292.

Anadón, P., Utrilla, R., 1993. Sedimentology and isotope geochemistry of lacustrine carbonates of the Oligocene Campins Basin, northeast Spain. Sedimentology 40, 699-720.

Andrews, J.E., 1991. Geochemical indicators of depositional and early diagenetic facies in Holocene carbonate muds, and their preservation potential during stabilisation. Chem. Geol. 93, 267-289.

Budd, D.A., 1989. Micro-rhombic calcite in limestones: a geochemical study of the Lower Cretaceous Thamama Group, U.A.E.. Sediment. Geol. 63, 293-311.

Burne, R.V., Bauld, J., DeDecker, P., 1980. Saline lake charophytes and their geological significance. J. Sediment. Petrol. 50, 281-293.

Calvo, J.P., Alonso Zarza, A.M., Garcia del Cura, M.A., 1989. Models of Miocene marginal lacustrine sedimentation in response to varied depositional regimes and source areas in the Madrid Basin (Central Spain). Palaeogeogr. Palaeoclimatol. Palaeoecol. 70, 199-214.

Calvo, J.P., Alonso Zarza, A.M., Garcia del Cura, M.A., Ordoñez, S., Rodriquez-Aranda, J.P., Sanz Montero, M.E., 1996. Sedimentary evolution of lake systems through Miocene, Madrid Basin. Paleoclimatic and paleohydrological constraints. In: Friend, P., Dabrio, C. (Eds.), Tertiary Basins of Spain. Cambridge University Press, pp. 272-277.

Cañaveras, J.C., Calvo, J.P., Hoyos, M., Ordoñez, S., 1996. Palaeomorphologic features on an Intra-Vallesian paleokarst, Tertiary Madrid Basin, significance of paleokarstic surfaces in continental basin analysis. In: Friend, P., Dabrio, C. (Eds.), Tertiary Basins of Spain. Cambridge University Press, pp. 278-284.

Capote, R., Femández-Casals, M.J., 1978. La tectónica postmiocena del sector Central de la Depresión del Tajo. Bol. Geol. Min. Esp. 89, 114-122.

Carpenter, S.J., Lohmann, K.C., 1992. Sr/Mg ratios of modem marine calcite: empirical indicators of ocean chemistry and precipitation rate. Geochim. Cosmochim. Acta 56, 1837-1849.

De Vicente, G., Gonzalez-Casado, J.M., Calvo, J.P., MuñozMartin, A., Giner, J., Rodriguez-Pascua, M., 1994. Evolución y estructuras alpinas del centro peninsular. Cuad. Lab. Xeol. Laxe 19, 175-190.

Dravis, J.J., 1989. Deep-burial microporosity in Upper Jurassic Haynesville oolitic grainstones, East Texas. Sediment. Geol. 63, 325-341.

Eugster, H.P., Kelts, K., 1983. Lacustrine chemical sediments. In: Goudie, A.S., Pye, K. (Eds.), Chemical Sediments and Geomorphology. Academic Press, London, pp. 321-368.

Folk, R.L., 1965. Some aspects of recrystallization in ancient limestones. In: Pray, L.C., Murray, R.C. (Eds.), Dolomitization and Limestone Diagenesis. Soc. Econ. Paleontol. Mineral. Spec. Publ. 13, 14-48.

Freytet, P., 1984. Les sédiments lacustres carbonatés et leur transformation par émersion et pédogénèse. Bull. Cent. Rech. Explor. Elf Aquitaine 8, 223-247.

Handford, C.R., Loucks, R.G., Moshier, S.O. (Eds.), 1989. Nature and Origin of Micro-rhombic Calcite and Associated Microporosity in Carbonate strata. Sediment. Geol. 63, 384 pp.

Junco, F., Calvo, J.P., 1983. Cuenca de Madrid. In: Geología de España, Vol. II. IGME, Madrid, pp. 534-543.

Kelts, K., Hsü, K.J., 1978. Freshwater carbonate sedimentation. In: Lerman, A. (Ed.), Lakes: Chemistry, Geology and Physics. Springer Verlag, Berlin, pp. 295-353.

Lasemi, Z., Sandberg, P.A., 1984. Transformation of aragonitedominated lime muds to microcrystalline limestones. Geology $12,420-423$.

Lasemi, Z., Sandberg, P.A., 1993. Microfabric and compositional clues to dominant mud mineralogy of micritic precursors. In: Rezak, R., Lavoie, D.L. (Eds.), Carbonate Microfabrics. Springer Verlag, Berlin, pp. 173-185.

Lasemi, Z., Sandberg, P.A., Boardman, M.R., 1990. New microtextural criterion for differentiation of compaction and early cementation in fine-grained limestones. Geology 18, 370-373.

Major, R.P., Wilber, J., 1991. Crystal habit, geochemistry and cathodoluminescence of magnesian calcite marine cements from the lower slope of Little Bahama Bank. Bull. Geol. Soc. Am. 103, 461-471.

Mazzullo, S.J., Bischoff, W.D., 1992. Meteoric calcitization and incipient lithification of recent high-magnesium calcite muds, Belize. J. Sediment. Petrol. 62, 196-207.

Morse, J.W., Casey, W.H., 1988. Ostwald processes and mineral paragenesis in sediments. Am. J. Sci. 288, 537-560.

Moshier, S.O., 1989a. Microporosity in micritic limestones: a review. Sediment. Geol. 63, 191-213.

Moshier, S.O., 1989b. Development of microporosity in a micritic limestone reservoir, Lower Cretaceous, Middle East. Sediment. Geol. 63, 217-240.

Müller, G., Irion, G., Förstner, U., 1972. Formation and diagenesis of inorganic $\mathrm{Ca}-\mathrm{Mg}$ carbonates in the lacustrine environment. Naturwissenschaften 59, 158-164.

Ordóñez, S., Calvo, J.P., Garcia del Cura, M.A., Hoyos, M., Alonso Zarza, A.M., 1991. Sedimentology of sodium sulphate deposits and special clays from the Tertiary Madrid Basin (Spain). In: Anadón, P., Cabrera, L., Kelts, K. (Eds.), Lacustrine Facies Analysis. Spec. Publ. Int. Assoc. Sedimentol. 13, 3753. 
Pedley, M., 1992. Freshwater (phytohern) reefs: the role of biofilms and their bearing on marine reef cementation. Sediment. Geol. 79, 255-274.

Pérez-González, A., 1982. Neógeno y Cuaternario de la llanura manchega y sus relaciones con la Cuenca del Tajo. Tesis Doct., Univ. Complutense de Madrid, 787 pp.

Platt, N.H., 1989. Lacustrine carbonates and pedogenesis: sedimentology and origin of palustrine deposits from the Early Cretaceous Rupelo Formation, W Cameros Basin, N Spain. Sedimentology 36, 665-684.

Rodríguez-Aranda, J.P., Calvo, J.P., Ordoñez, S., 1991. Transición de abanicos aluviales a evaporitas en el Mioceno del borde oriental de la Cuenca de Madrid (Sector Barajas de Melo-Illana). Rev. Soc. Geol. Esp. 4, 33-50.

Saller, A.H., Moore, C.H., 1989. Meteoric diagenesis, marine diagenesis and microporosity in Pleistocene and Oligocene limestones, Enewetak Atoll, Marshall Island. Sediment. Geol. 63, 253-272.

Sandberg, P.A., Hudson, J.D., 1983. Aragonite relic preservation in Jurassic calcite-replaced bivalves. Sedimentology 30, 879892.

Sanz, M.E., 1994. Sedimentología de las formaciones neógenas del sur de la Cuenca de Madrid, con énfasis en los procesos kársticos asociados a las rupturas sedimentarias del Plioceno. Tesis Doct., Univ. Complutense de Madrid, 333 pp.

Sanz, M.E., Wright, V.P., 1994. Modelo alternativo para el desarrollo de calcretas: un ejemplo del Plio-Cuaternario de la Cuenca de Madrid. Geogaceta 16, 116-119.

Sanz, M.E., Sese, C., Calvo, J.P., 1992. Primer hallazgo de micromamíferos de edad Turoliense en la Cuenca de Madrid.
Estud. Geol. 48, 171-178.

Sanz, E., Rodriguez, J.P., Calvo, J.P., Ordoñez, S., 1994. Tertiary gypsum in the Madrid Basin: diagnostic criteria for interpreting detrital gypsum in continental evaporitic sequences. In: Renaut, R., Last, W. (Eds.), Sedimentary and Geochemistry of Modern and Ancient Saline Lakes. Soc. Econ. Paleontol. Mineral. Spec. Publ. 50, 217-228.

Savard, M.M., Viezer, J., Hinton, R., 1995. Cathodoluminescence at low $\mathrm{Fe}$ and $\mathrm{Mn}$ concentrations: a sims study of zones in natural calcites. J. Sediment. Res. A65, 208-213.

Steinen, R.P., 1978. On the diagenesis of lime mud: scanning electron microscopic observations of subsurface material from Barbados, W.I. . J. Sediment. Petrol. 48, $1139-1148$.

Steinen, R.P., 1982. SEM observations of the replacement of Bahamian aragonitic mud by calcite. Geology 10, 471-475.

Talbot, M.R., 1990. A review of the palaeohydrological interpretation of carbon and oxygen isotopic ratios in primary lacustrine carbonates. Chem. Geol. (Isot. Geosci. Sect.) 80 . 261-279.

Tucker, M.E.. Wright, V.P., 1990. Carbonate Sedimentology. Blackwell, Oxford, $482 \mathrm{pp}$.

Veizer, J., 1977. Diagenesis of pre-Quaternary carbonates as indicated by tracer studies. J. Sediment. Petrol. 47, 565-581.

Wiggins, W.D., 1986. Geochemical signatures in carbonate matrix and their relation to deposition and diagenesis, Pennsylvanian Marble Falls Limestone, Central Texas. J. Sediment. Petrol. 56, 771-783.

Wright, V'P., Alonso Zarza, A.M., 1992. Significado de la composición isotópics $\left(\delta^{13} \mathrm{C}\right.$ y $\left.\delta^{18} \mathrm{O}\right)$ en paleosuelos carbonatados. Mioceno de la Cuenca de Madrid. Geogaceta 11. 61-63. 